\title{
Feasibility of CLIL Implementation in the Education System of Azerbaijan: Attitude towards CLIL and the English Language in Higher Educational Institutions
}

\author{
Jamala I. Mammadova ${ }^{1}$ \\ ${ }^{1}$ English Language and Literature Department, Khazar University, Baku, Azerbaijan \\ Correspondence: Jamala I. Mammadova, English Language and Literature Department, Khazar University, Baku, \\ Azerbaijan. Tel: 99-412-421-79-16. E-mail: jamala.mammadova@gmail.com
}

Received: July 21, 2016 Accepted: August 12, 2016 Online Published: September 23, 2016

doi:10.5539/ijel.v6n5p188 URL: http://dx.doi.org/10.5539/ijel.v6n5p188

\begin{abstract}
This article examines the feasibility of introducing Content and Language Integrated Learning (CLIL) in the education system of Azerbaijan, and determining the most preferred target language for this matter. Azerbaijan is a country with traditions of multilingualism. There are certain challenges within the society in terms of ensuring communication among different linguistic groups, which necessitate examining appropriate language policy and acquisition solutions. CLIL, which enables individuals to learn more than two languages at relatively high level, seems to be a promising approach for overcoming the linguistic communication problems in Azerbaijan, and enabling to take socio-economic and cognitive advantages of multilingualism.

Whereas the question of feasibility of certain language acquisition approach in a specific country requires studying several dimensions such as public attitude, economic aspects and legal framework, the focus of the empirical research of this article is directed to learning the attitude to CLIL, which is a relatively under researched field. In the research part, it is sought to answer questions whether CLIL is supported among students in Azerbaijan, and which foreign language is preferred most. Moreover, it was sought to examine the relationship among the variables of gender, social class, existing language skills, as well as attitudes to CLIL and target language preference.

It was found that CLIL is supported by participants, and English is the most preferred foreign language. It indicates that multilingual societies like Azerbaijan are supportive of language acquisition choices that help preserve and develop multilingualism. Moreover, it was found that attitude to language acquisition method and the language itself differ due to income level and existing language skills.
\end{abstract}

Keywords: CLIL, the English language, Azerbaijan, attitude, language learning, multilingualism

\section{Introduction}

This article aims to evaluate the feasibility of implementation of CLIL in the education system of Azerbaijan-a country with traditions of multilingualism and certain challenges to ensuring linguistic coherence of the society. It also aims to study the attitude among university students to foreign languages and examine the relationship between individual's existing language skills, attitude to CLIL and foreign language preference.

In multilingual societies, what language(s) to learn and how to learn are tough questions for individuals and societies alike for which no easy answer exists. In the age of technology, when people need to learn more and more content, it is becoming increasingly difficult to adjust the balance between the efforts that people need to invest in content and language learning. This puts additional strains on available differences among different social groups, especially in multilingual societies. On the other hand, accessing information in foreign languages, and communicating with external environments are becoming a necessity in the fiercely competitive globalized age.

In other words, one needs to devise solutions to address linguistic education rights of citizens on the one hand, while at the same time one needs to look for individual cognitive and socio-economic advantages of multilingualism on the other. 


\subsection{Multilingual Context of Azerbaijan}

Azerbaijan is a country with significant linguistic diversity and intensive social and economic communication with the external world.

The traditional tolerance in the society and government's strong emphasis on multiculturalism are the factors facilitating implementation of effective means to address the linguistic rights of people.

It should also be mentioned that the character of multilingualism in Azerbaijan requires certain actions to be taken to ensure social coherence. A significant dimension of multilingualism in Azerbaijan emerged due to historical reasons. The two centuries-old colonial period made a specific impact on the linguistic landscape of Azerbaijan. The intensive policy of Russification through education, especially during the Soviet period created a sizeable Russian-speaking segment in the society. With regard to Russian, Azerbaijan displays typical signs of survival of the metropolitan language in post-colonial context. It puts certain pressure on the role of Azerbaijani, the language of the majority. It is a matter of significant public interest and subject of ongoing discussions in the society, whereby some consider it to be a dividing factor in the society.

According to the census held in 2009, the population number in the Republic of Azerbaijan was 8.9 million. Azerbaijani and Russian are the two most widely used languages in the Republic of Azerbaijan (The State Statistical Committee of the Republic of Azerbaijan, 2015). It should be noted that this dimension of multilingualism in Azerbaijan has emerged not as a matter of language spoken by ethnic groups, but more as a result of educational multilingualism, and the policy of Russification (Swietochowski, 1986).

In addition to ethnic Azerbaijanis, who constitute the absolute majority in the country, Azerbaijan is home to several ethnic minorities. Being situated in a cross-road of continents, Azerbaijan has historically been exposed to different external political and cultural influences - a factor that is being reinforced by virtue of accelerated movement of persons, goods, services and capital in a globalized world.

The linguistic landscape of the education system of Azerbaijan is quite diverse. In addition to Azerbaijani, other languages, most notably, Russian, English, Georgian and French are widely used as a medium of instruction in kindergarten, primary, secondary and tertiary levels (Pashayeva, 2015).

More than 90 percent of students in the general-education schools receive their education in Azerbaijani. In the school year of 2013/2014, 92.9\% (1197761) of the students enrolled in general education schools was receiving their education in Azerbaijani. The share of students in Russian, English, Georgian and Turkish schools was $7.05 \%, 0.1 \%, 0.09 \%$ and $0.04 \%$ respectively. In 2013, there were 15 general-education schools, where the only language of instruction is Russian (Vzglyad.az, 2013). In 314 schools, there were Russian sectors (Vzglyad.az, 2013). There is a negative trend in the number of first enrollment education in the Azerbaijani sector. Statistics indicate a decline in the relative number of students in Azerbaijani schools, and growth in Russian schools. Share of first enrollments in Russian schools rose from 6\% in 2008 to 8\% in 2012 (Abdullayeva, 2014).

Overall, it can be said that Azerbaijan has a relatively liberal linguistic setting with some signs of elite multilingualism. Relative importance of Azerbaijani is ensured by the fact that it is the sole state language, and the vast majority of the population speaks this language. However, unmanaged linguistic trends in the education sector such as creeping Russification of schools and neglect of Azerbaijani may have some unintended consequences for the role of Azerbaijani as the state language and the coherence of society.

The Content and Language Integrated Learning (CLIL) approach seems to be a very promising solution for preventing potential linguistic fragmentation in Azerbaijan. It would help fully establish Azerbaijani as the primary language of communication in the society on the one hand, and facilitate the learning of desired languages on the other.

\subsection{CLIL}

CLIL is the English acronym for Content and Language Integrated Learning. Alternative abbreviations in other languages are EMILE (Enseignementd' uneMatièreparl' intègrationd' une Langue Etrangère) in French, AICLE (Aprendizaje Integrado de Contenidos y Lengua Extranjera) in Spanish and "Bili" (Bilingualer Unterricht =BU) in German, whereas the term "bilingual" in the German context does not imply advanced mastery of a second or foreign language, but partial second/foreign language competence (Brüning \& Purrmann, 2014).

According to David Marsh, "CLIL refers to situations where subjects, or parts of subjects, are taught through a foreign language with dual-focused aims, namely the learning of content and the simultaneous learning of a foreign language" (cited in Marenzi et al., 2012, p. 104). According to Marsh, "CLIL offers opportunities to allow youngsters to use another language naturally, in such a way that they soon forget about the language and 
only focus on the learning topic" (Marsh \& Langé, 2000, p. 6).

Coyle et al. (2010) mention CLIL as "a dual-focused educational approach in which an additional language is used for the learning and teaching both content and language," and the additional language is usually learner's desired foreign language, but it might also be a second language or some form of heritage or community language (Coyle et al., 2010, p. 1).

Content Language Integrated Learning is an educational approach that is applied to address inter alia the linguistic rights in multiethnic societies (Starkey, 2002) and to take educational and socio-economic advantages of multilingualism (Coyle et al., 2010). Both the socio-economic considerations and issues of multi-ethnicity, which are main factors when it comes to application of CLIL, are relevant for the Republic of Azerbaijan.

\subsection{Previous Research}

Cenoz (2001) and Merisuo-Storm (2007) found that achievement of students in second language learning depends on their attitude to a target language. The more positive attitude to foreign languages results in higher achievements of students in L2.

In terms of attitude to CLIL and foreign languages, a research was conducted Lasagabaster \& Sierra (2009) to analyze the effectiveness of CLIL and attitude to English among students in the bilingual context in the Basque Country in Spain. They found a positive attitude of learners towards English within CLIL contexts. This study also revealed differences in attitude due to gender in that female learners appeared to have more positive attitude towards the English language compared to male learners (Lasabagaster \& Sierra, 2009). In terms of the role of social class, Lasabagaster \& Sierrea (2009) did not find any significant relationship. Another similar research conducted by Papaja (2012), who studied the attitude of university students towards CLIL in Poland, revealed positive attitude of learners towards English. A study by Ibarraran et al. (2008), who examined attitude to languages among 125 local and immigrant students in the Basque country, found that immigrant students' attitude towards the English language is far more positive than that of local students. In terms of relationship between existing language skills and attitude to English, the study by Ardeo (2013) deserves attention. Ardeo found that both monolingual (Spanish) and bilingual (Spanish/Basque) students' attitudes towards English were similarly positive.

The study of gender and attitude towards learning languages is also one of the aspects that draw an attention in this article when it comes to attitude towards CLIL and language learning in general. Wright (1999), Kobayashi (2002), Cenoz (2001) studies found significant differences between male and female attitude towards learning languages; in all afore-mentioned studies about attitude, girls demonstrated more positive attitude towards language learning compared to boys. Kobayashi (2002) study maintains that Japanese women are more willing to learn English than Japanese men in the Japanese context. In a similar vein, Lasabagaster \& Sierra (2009) maintain female learners to have better attitude towards learning languages compared to boys as mentioned above. On the contrary, Merisuo-Storm (2007) study maintains no gender differences in the attitude of the participants towards language learning among Finnish pupils on the primary level. On the national level, this paper represents a pioneering attempt to study the attitude to CLIL and the English language in Azerbaijan.

\section{Method}

This article is motivated by the following hypotheses: 1) Is CLIL supported in Azerbaijan by university students; 2) What is the most preferred target language by university students in Azerbaijan.

For research questions on attitude to CLIL and foreign languages, surveys are conducted, which is considered to be the main method for studying public opinion (Walden, 2014).

\subsection{Survey Questionnaire}

The questionnaire was self-developed by the author by drawing on findings of Ellis, who identified four main social factors (age, sex, social class and ethnic identity) that influence the attitude to languages (Ellis, 1994). In developing the questionnaire, this work considered those factors while making certain adjustments based on local culture and circumstances. First of all, asking direct questions about the income level is considered to be inappropriate in an Azerbaijani context. To address this limitation, an indirect question was asked whether the participant was affiliated with a private or public institution, bearing in mind that participants affiliated with private schools, which charge a high fee, usually have more income than those affiliated with public schools. The question of ethnic identity was yet another challenge. As noted by Gudykunst \& Ting-Toomey (1990), "ethnicity is a slippery concept" (Gudykunst \& Ting-Toomey in Ellis, 1994). Fishman and Garcia mention the language as one of the key criteria of ethnicity (Fishman \& García, 2010). Max Weber emphasizes the role of subjective perception in ethnic identification (Weber, 1978). In the Azerbaijani context, subjective aspect of ethnicity is 
relatively strong. Individuals would tend to indicate their ancestors' ethnicity and mother tongue as theirs regardless of actual level of possession of that language. Taking data based on that criterion would significantly neglect the variable of Russian-speakers, who mostly consider themselves Azerbaijanis, but constitute a significant distinct socio-linguistic group in Azerbaijan. Therefore, the survey questionnaire asks a question on the language of secondary school, which is a decisive factor in L1 acquisition in the Azerbaijani context.

The survey included two main questions ("Do you support the implementation of CLIL in the education system of Azerbaijan?", "Which foreign language do you consider the best foreign language in Azerbaijan?") and questions on demographic indicators (age, gender, affiliated university, language of secondary school education). Before survey, the participants were briefed orally about CLIL and CLIL practices including its shortcomings. After the collection of the data, answers were aggregated and codified for analysis.

\subsection{Sampling Method}

Non-probability purposive sampling method was employed in this article. This method was used for two reasons. First, probability method for finding out the attitude among the entire population ( $\mathrm{N}=9.1$ million) was not feasible due to the limited resources. Second, even if probability sampling was possible, it would not be appropriate given the specific nature of the research questions. The research questions, which relate to educational changes in the field of language policy and planning, required certain knowledge from the sample participants and necessitated taking samples from specific sites. As noted by Hult \& Johnson, schools and other education sites are most appropriate places for conducting research on questions related to language policy and planning (Hult \& Johnson, 2015). Taking into account this qualitative aspect, this article focused its research on those people who are exposed to education and foreign languages.

The survey was conducted from 2012-2015 involving 533 students from four educational institutions (Baku Slavic University, KhazarUnivesity, Qafqaz University, Azerbaijan University of Languages) in Azerbaijan. Survey questions were prepared in paper and distributed to the sample participants in person. Ethical considerations of the research were taken into account: participation at the survey was voluntary; the participants were informed about the research objectives and the future fate of the questionnaires.

\subsection{Participants}

Undergraduate students from 4 higher educational institutions (two state, two private), Baku Slavic University(state), Azerbaijan University of Languages (state), Khazar University (private), Qafqaz University (private) participated in this survey.

Table 1. Demographic indicators of sample participants (students)

\begin{tabular}{ll}
\hline Demographic indicator & Number \\
\hline Male, & 237 \\
including, & \\
- those enrolled in public universities & 29 \\
- those enrolled in private universities & 208 \\
Female & 296 \\
including, & \\
- those enrolled in public universities & 31 \\
- those enrolled in private universities & 265 \\
Total & 533 \\
Mean age (SD) & $21.19(.92)$ \\
\hline
\end{tabular}

Students were selected for this study as direct participants of the education process. Total, 533 valid responses were registered (female 296, male 237, mean age $=21.19, \mathrm{SD}=.92$ ) (See table 1).

All four higher educational institutions (Khazar University, Qafqaz University, Azerbaijan University of Languages and Baku Slavic University) have relevance to languages and foreign culture. Based on ownership form of affiliated institution, two sub-groups were distinguishable: (1) Students enrolled at private universities (n $=473$; female 265, male 208; mean age $=21.11, \mathrm{SD}=.88)$; (2) Students enrolled at public universities $(\mathrm{n}=60$; female 31, male 29, mean age $=21.78, \mathrm{SD}=1.07$ ).

Khazar University is a private university founded in 1991 in Baku, Azerbaijan. Khazar was ranked first among Azerbaijan universities according to QS World University Rankings. Surveys at Khazar University were conducted in five batches in October 2013, February 2014, October 2014 and March 2015 involving 2nd year, 
3rd year and 4th year undergraduate students. 406 students were provided with paper questionnaires, 392 participants responded the questionnaires $(\mathrm{n}=392$; female 221 , male 171 ; mean age $=21.05 ; \mathrm{SD}=.89$; $) 4$ th-year students $(\mathrm{n}=21$; female 18 , male 3 ; mean age $=22.52, \mathrm{SD}=1.03)$ had previous knowledge on CLIL from the class they had taken a course on Language Acquisition, where they were lectured on language acquisition theories, including CLIL and other teaching methods. Remaining students did not have previous knowledge on CLIL ( $\mathrm{n}=371$; female 203, male 168; mean age $=21.06$; $\mathrm{SD}=.91$ ). They received briefing on that matter.

Qafqaz University is a private university. It was founded in 1993. The English language is being taught by rule learning method. In QS World University Rankings, it ranked second among Azerbaijani universities after Khazar University. The University does not have linguistic "sectors". Most courses are offered in English. Some are offered in Azerbaijani, Turkish and few in Russian. Survey at Qafqaz University was conducted on November 15, 2012. The sample participants were 2nd and 3rd year students. Total 86 students received questionnaires in a paper form. 81 students returned questionnaires $(\mathrm{n}=81$; female 44 , male 37 ; mean age $=$ $21.40, \mathrm{SD}=.75)$. The participants did not have previous knowledge on CLIL. They received briefing on that matter.

Azerbaijan University of Languages is a public university located in Baku, Azerbaijan. During the Soviet times, it was named Azerbaijan Pedagogical Institute of Foreign Languages. After the independence, it was renamed to Azerbaijan University of Languages. It is the most important higher-educational institution of Azerbaijan in the field of Roman-German language and literature. The university administration indicated available groups, which then received questionnaires in paper form during teaching hours. In total, 26 students were provided with questionnaires. They were undergraduate students from different faculties and years. 25 students returned filled questionnaires $(\mathrm{n}=25$; female 14 , male 12 ; mean age $=21.52, \mathrm{SD}=0.96)$. The participants did not have previous knowledge on CLIL. They received briefing on that matter before the survey. The survey was conducted on March 16, 2015.

Baku Slavic University is a public university located in Baku. It is specialized in teaching Slavic languages. The university was founded in 1946 as the Azerbaijan State Institute of Teachers on Russian Language and Literature. In 2000, the Institute was renamed to Baku Slavic University. This survey site was of special interest given its strong traditions in studies of the Russian language and literature, an important factor in educational multilingualism in Azerbaijan. The University administration indicated available groups, which then received questionnaires in paper form during teaching hours. In total, 37 students were provided with questionnaires. 35 students returned filled questionnaires $(\mathrm{n}=35$; female 18 , male 17 ; mean age $=21.97$, $\mathrm{SD}=1.12)$. The participants did not have previous knowledge on CLIL. They received briefing on that matter before the survey. The survey was conducted on March 17, 2012.

\subsection{Data Analysis}

Statistical 13 software from Dell was used to conduct statistical analysis in this article. Confidence interval calculation was carried out on the binary data on attitude to CLIL, and foreign languages to estimate the population proportion $(\pi)$. For testing statistical dependence between two variables, the Chi-square test was used. The predetermined significance level for $\mathrm{p}$ value was set at 5 percent $(\alpha=.05)$. The Chi-square test was not conducted involving the variable of age since the sample group was quite age-homogeneous with low standard deviation of the mean age (mean age $=21.19, S D=.92$ ). Item reliability test of the questionnaire revealed an acceptable level of internal consistency of the data, with Cronbach alpha $=.79078$.

\section{Results}

\subsection{Attitude to CLIL}

The results of statistical analysis on students' attitude to CLIL are presented below.

Table 2. Observed frequencies: support for CLIL

\begin{tabular}{lllll}
\hline Category & Count & Cumulative Count & Percent & Cumulative Percent \\
\hline Yes & 449 & 449 & 84.24015 & 84.2402 \\
No & 84 & 533 & 15.75985 & 100.0000 \\
Missing & 0 & 533 & 0.00000 & 100.0000 \\
\hline
\end{tabular}

The descriptive statistics tests revealed that majority, $84.2 \%$ of participants supported CLIL implementation in the education system of Azerbaijan (see Table 2). At confidence level of $\alpha=.05$, the confidence interval 
calculation indicated that the estimated population proportion of CLIL supporters equals to $84.2 \% \pm 3.1 \%$ $(81.1 \%<\pi<87.3 \%)$

Table 3. Chi-square test: Gender (2) x support for CLIL (2)

\begin{tabular}{llll}
\hline Statistic & Chi-square & $\mathrm{df}$ & $\mathrm{P}$ \\
\hline Pearson Chi-square & .4016344 & $\mathrm{df}=1$ & $\mathrm{p}=.52625$ \\
M-L Chi-square & .4003322 & $\mathrm{df}=1$ & $\mathrm{p}=.52692$ \\
\hline
\end{tabular}

Chi-square testing did not reveal statistically significant correlation between the gender and attitude to CLIL, 2 $(1, \mathrm{n}=533)=.40, \mathrm{p}>.05($ see Table 3$)$.

Table 4. Observed frequencies: support for CLIL due to gender

\begin{tabular}{llll}
\hline Gender & $\begin{array}{l}\text { Support for CLIL } \\
\text { Yes }\end{array}$ & $\begin{array}{l}\text { Support for CLIL } \\
\text { No }\end{array}$ & $\begin{array}{l}\text { Row } \\
\text { Totals }\end{array}$ \\
\hline Male & 197 & 40 & 237 \\
Column \% & $43.88 \%$ & $47.62 \%$ & \\
Row \% & $83.12 \%$ & $16.88 \%$ & \\
Total \% & $36.96 \%$ & $7.50 \%$ & $44.47 \%$ \\
Female & 252 & 44 & 296 \\
Column \% & $56.12 \%$ & $52.38 \%$ & \\
Row \% & $85.14 \%$ & $14.86 \%$ & $55.53 \%$ \\
Total \% & $47.28 \%$ & $8.26 \%$ & 533 \\
Totals & 449 & 84 & $100.00 \%$ \\
Total \% & $84.24 \%$ & $15.76 \%$ & \\
\hline
\end{tabular}

Both male and female participants supported CLIL implementation in Azerbaijan almost on the equal rate with $83.1 \%$ and $85.1 \%$ respectively (see Table 4 ).

Table 5. Chi-square test: ownership form (2) x support for CLIL (2)

\begin{tabular}{llll}
\hline Statistic & Chi-square & $\mathrm{df}$ & $\mathrm{P}$ \\
\hline Pearson Chi-square & 1.776860 & $\mathrm{df}=1$ & $\mathrm{p}=.18254$ \\
M-L Chi-square & 1.645057 & $\mathrm{df}=1$ & $\mathrm{p}=.19963$ \\
\hline
\end{tabular}

Attitude to CLIL did not differ due to the form of ownership of the educational institutions, which the sample participants were affiliated with. The chi-square test did not reveal any statistically significant relationship between the variables of ownership form and support for CLIL, $2(1, \mathrm{n}=533)=1.8, \mathrm{p}>.05$ (see Table 5).

Table 6. Observed frequencies: support for CLIL due to ownership form of educational institutions

\begin{tabular}{llll}
\hline Ownership form & $\begin{array}{l}\text { Support for CLIL } \\
\text { Yes }\end{array}$ & $\begin{array}{l}\text { Support for CLIL } \\
\text { No }\end{array}$ & $\begin{array}{l}\text { Row } \\
\text { Totals }\end{array}$ \\
\hline Public & 47 & 13 & 60 \\
Column \% & $10.47 \%$ & $15.48 \%$ & \\
Row \% & $78.33 \%$ & $21.67 \%$ & \\
Total \% & $8.82 \%$ & $2.44 \%$ & $11.26 \%$ \\
Private & 402 & 71 & 473 \\
Column \% & $89.53 \%$ & $84.52 \%$ & \\
Row \% & $84.99 \%$ & $15.01 \%$ & $88.74 \%$ \\
Total \% & $75.42 \%$ & $13.32 \%$ & 533 \\
Totals & 449 & 84 & $100.00 \%$ \\
Total \% & $84.24 \%$ & $15.76 \%$ & \\
\hline
\end{tabular}

$78.3 \%$ of students enrolled in public universities and $85 \%$ of students enrolled in private universities supported implementation of CLIL (see Table 6). 
Table 7. Chi-square test: language of secondary school education (2) x Support for CLIL (2)

\begin{tabular}{llll}
\hline Statistic & Chi-square & Df & $\mathrm{P}$ \\
\hline Pearson Chi-square & 12.62415 & $\mathrm{df}=1$ & $\mathrm{p}=.00038$ \\
M-L Chi-square & 11.15736 & $\mathrm{df}=1$ & $\mathrm{p}=.00084$ \\
\hline
\end{tabular}

Chi-square test of independence indicated statistically significant relationship between the first language and attitude to CLIL, $2(1, \mathrm{n}=533)=12.6, \mathrm{p}<.05($ see Table 7$)$.

Table 8. Observed frequencies: support for CLIL due to the language of secondary school education

\begin{tabular}{llll}
\hline Language of secondary school education & $\begin{array}{l}\text { Support for CLIL } \\
\text { Yes }\end{array}$ & $\begin{array}{l}\text { Support for CLIL } \\
\text { No }\end{array}$ & $\begin{array}{l}\text { Row } \\
\text { Totals }\end{array}$ \\
\hline Azerbaijani & 382 & 58 & 440 \\
Column \% & $85.08 \%$ & $69.05 \%$ & \\
Row \% & $86.82 \%$ & $13.18 \%$ & \\
Total \% & $71.67 \%$ & $10.88 \%$ & $82.55 \%$ \\
Russian & 67 & 26 & 93 \\
Column \% & $14.92 \%$ & $30.95 \%$ & \\
Row \% & $72.04 \%$ & $27.96 \%$ & \\
Total \% & $12.57 \%$ & $4.88 \%$ & $17.45 \%$ \\
Totals & 449 & 84 & 533 \\
Total \% & $84.24 \%$ & $15.76 \%$ & $100.00 \%$ \\
\hline
\end{tabular}

Graduates of Russian schools were less likely (72\%) to support CLIL than those attending Azerbaijani (86.8 \%) schools (see Table 8).

\subsection{Foreign Language-Preference}

The results of statistical analysis on foreign language preference are given below.

Table 9. Observed frequencies: foreign language preference

\begin{tabular}{lllll}
\hline Category & Count & $\begin{array}{l}\text { Cumulative } \\
\text { Count }\end{array}$ & Percent & $\begin{array}{l}\text { Cumulative } \\
\text { Percent }\end{array}$ \\
\hline English & 457 & 457 & 85.74109 & 85.7411 \\
Other & 40 & 497 & 7.50469 & 93.2458 \\
Russian & 36 & 533 & 6.75422 & 100.0000 \\
Missing & 0 & 533 & 0.00000 & 100.0000 \\
\hline
\end{tabular}

The descriptive statistics tests revealed that majority (85.7\%) of participants preferred English. Out of 533 students 457 indicated English as the most preferred foreign language. 36 students (6.6\%) indicated preference for Russian, 40 students (7.5\%) favored other languages (see Table 9). At confidence level of $\alpha=.05$, the confidence interval calculation indicated that the estimated population proportion of English supporters equals to $85.7 \% \pm 2.97 \%(82.73 \%<\pi<88.67 \%)$.

Table 10. Chi-square test: language of secondary school education (2) $\mathrm{x}$ foreign language preference (3)

\begin{tabular}{llll}
\hline Statistic & Chi-square & $\mathrm{df}$ & $\mathrm{P}$ \\
\hline Pearson Chi-square & 43.56757 & $\mathrm{df}=2$ & $\mathrm{p}=.00000$ \\
M-L Chi-square & 35.25305 & $\mathrm{df}=2$ & $\mathrm{p}=.00000$ \\
\hline
\end{tabular}

Chi-square test of independence indicated a statistically significant relationship between the first language and foreign language preference, $2(2, \mathrm{n}=533)=43.6, \mathrm{p}<.05($ see Table 10$)$. 
Table 11. Observed frequencies: foreign language preference due to the language of secondary school education

\begin{tabular}{lllll}
\hline $\begin{array}{l}\text { Language of secondary } \\
\text { school education }\end{array}$ & $\begin{array}{l}\text { Preferred FL } \\
\text { English }\end{array}$ & $\begin{array}{l}\text { Preferred FL } \\
\text { Other }\end{array}$ & $\begin{array}{l}\text { Preferred FL } \\
\text { Russian }\end{array}$ & $\begin{array}{l}\text { Row } \\
\text { Totals }\end{array}$ \\
\hline Azerbaijani & 397 & 25 & 18 & 440 \\
Column \% & $86.87 \%$ & $62.50 \%$ & $50.00 \%$ & \\
Row \% & $90.23 \%$ & $5.68 \%$ & $4.09 \%$ & \\
Total \% & $74.48 \%$ & $4.69 \%$ & $3.38 \%$ & $82.55 \%$ \\
Russian & 60 & 15 & 18 & 93 \\
Column \% & $13.13 \%$ & $37.50 \%$ & $50.00 \%$ & \\
Row \% & $64.52 \%$ & $16.13 \%$ & $19.35 \%$ & \\
Total \% & $11.26 \%$ & $2.81 \%$ & $3.38 \%$ & $17.45 \%$ \\
Totals & 457 & 40 & 36 & 533 \\
Total \% & $85.74 \%$ & $7.50 \%$ & $6.75 \%$ & $100.00 \%$ \\
\hline
\end{tabular}

The participants, who were graduates of Russian schools, were less likely (64.5\%) to support English than those attending Azerbaijani schools (90\%) (see table 11).

Table 12. Chi-square test: Gender (2) x foreign language preference (3)

\begin{tabular}{llll}
\hline Statistic & Chi-square & $\mathrm{df}$ & $\mathrm{P}$ \\
\hline Pearson Chi-square & 1.195163 & $\mathrm{df}=2$ & $\mathrm{p}=.55014$ \\
M-L Chi-square & 1.212587 & $\mathrm{df}=2$ & $\mathrm{p}=.54537$ \\
\hline
\end{tabular}

Chi-square test of independence did not reveal any statistically significant relationship between the variable of gender and foreign language preference, $2(2, \mathrm{n}=533)=1.2, \mathrm{p}>.05$ (see Table 12).

Table 13. Observed frequencies: Foreign language preference due to gender

\begin{tabular}{lllll}
\hline Gender & $\begin{array}{l}\text { Preferred FL } \\
\text { English }\end{array}$ & $\begin{array}{l}\text { Preferred FL } \\
\text { Other }\end{array}$ & $\begin{array}{l}\text { Preferred FL } \\
\text { Russian }\end{array}$ & $\begin{array}{l}\text { Row } \\
\text { Totals }\end{array}$ \\
\hline Male & 205 & 19 & 13 & 237 \\
Column $\%$ & $44.86 \%$ & $47.50 \%$ & $36.11 \%$ & \\
Row \% & $86.50 \%$ & $8.02 \%$ & $5.49 \%$ & \\
Total \% & $38.46 \%$ & $3.56 \%$ & $2.44 \%$ & $44.47 \%$ \\
Female & 252 & 21 & 23 & 296 \\
Column $\%$ & $55.14 \%$ & $52.50 \%$ & $63.89 \%$ & \\
Row \% & $85.14 \%$ & $7.09 \%$ & $7.77 \%$ & \\
Total \% & $47.28 \%$ & $3.94 \%$ & $4.32 \%$ & $55.53 \%$ \\
Totals & 457 & 40 & 36 & 533 \\
Total \% & $85.74 \%$ & $7.50 \%$ & $6.75 \%$ & $100.00 \%$ \\
\hline
\end{tabular}

Percentage of preference for English was similarly high among male and female respondents, with respectively $86.5 \%$ and $85.1 \%$. Attitude to Russian also did not differ significantly, with $5.5 \%$ of male participants, and $7.8 \%$ of female respondents preferring this language (see Table 13).

Table 14. Chi-square test: Ownership form (2) x foreign language preference (3)

\begin{tabular}{llll}
\hline Statistic & Chi-square & $\mathrm{df}$ & $\mathrm{P}$ \\
\hline Pearson Chi-square & 11.54016 & $\mathrm{df}=2$ & $\mathrm{p}=.00312$ \\
M-L Chi-square & 9.543595 & $\mathrm{df}=2$ & $\mathrm{p}=.00847$ \\
\hline
\end{tabular}

Chi-square test of independence revealed statistically significant relationship between the variable of ownership form of participants' universities and their foreign language preference, $2(2, \mathrm{n}=533)=11.5, \mathrm{p}<.05$ (see Table 14). 
Table 15. Observed frequencies: foreign language preference due to ownership form of educational institutions

\begin{tabular}{lllll}
\hline Ownership form & $\begin{array}{l}\text { Preferred FL } \\
\text { English }\end{array}$ & $\begin{array}{l}\text { Preferred FL } \\
\text { Other }\end{array}$ & $\begin{array}{l}\text { Preferred FL } \\
\text { Russian }\end{array}$ & $\begin{array}{l}\text { Row } \\
\text { Totals }\end{array}$ \\
\hline Public & 43 & 10 & 7 & 60 \\
Column \% & $9.41 \%$ & $25.00 \%$ & $19.44 \%$ & \\
Row \% & $71.67 \%$ & $16.67 \%$ & $11.67 \%$ & \\
Total \% & $8.07 \%$ & $1.88 \%$ & $1.31 \%$ & $11.26 \%$ \\
Private & 414 & 30 & 29 & 473 \\
Column \% & $90.59 \%$ & $75.00 \%$ & $80.56 \%$ & \\
Row \% & $87.53 \%$ & $6.34 \%$ & $6.13 \%$ & \\
Total \% & $77.67 \%$ & $5.63 \%$ & $5.44 \%$ & $88.74 \%$ \\
Totals & 457 & 40 & 36 & 533 \\
Total \% & $85.74 \%$ & $7.50 \%$ & $6.75 \%$ & $100.00 \%$ \\
\hline
\end{tabular}

Students enrolled in private universities were more likely to indicate English as their preferred language than students enrolled in public universities, with $87.5 \%$ versus $71.7 \%$ of respective participants. Moreover, students enrolled in public universities were more likely to prefer Russian than those enrolled in private universities (see Table 15).

\subsection{Other}

Table 16. Chi-square test: Support for CLIL (2) x foreign language preference (3)

\begin{tabular}{llll}
\hline Statistic & Chi-square & $\mathrm{Df}$ & $\mathrm{P}$ \\
\hline Pearson Chi-square & 22.76852 & $\mathrm{df}=2$ & $\mathrm{p}=.00001$ \\
M-L Chi-square & 19.03729 & $\mathrm{df}=2$ & $\mathrm{p}=.00007$ \\
\hline
\end{tabular}

Chi-square test of independence also revealed statistically significant relationship between attitudes to CLIL and foreign languages, $2(2, \mathrm{n}=533)=22.8, \mathrm{p}<.05$ (see Table 16$)$.

Table 17. Observed frequencies: Foreign language preference due to attitude to CLIL

\begin{tabular}{lllll}
\hline Support for CLIL & $\begin{array}{l}\text { Preferred FL } \\
\text { English }\end{array}$ & $\begin{array}{l}\text { Preferred FL } \\
\text { Other }\end{array}$ & $\begin{array}{l}\text { Preferred FL } \\
\text { Russian }\end{array}$ & $\begin{array}{l}\text { Row } \\
\text { Totals }\end{array}$ \\
\hline Yes & 399 & 26 & 24 & 449 \\
Column \% & $87.31 \%$ & $65.00 \%$ & $66.67 \%$ & \\
Row \% & $88.86 \%$ & $5.79 \%$ & $5.35 \%$ & \\
Total \% & $74.86 \%$ & $4.88 \%$ & $4.50 \%$ & $84.24 \%$ \\
No & 58 & 14 & 12 & 84 \\
Column \% & $12.69 \%$ & $35.00 \%$ & $33.33 \%$ & \\
Row \% & $69.05 \%$ & $16.67 \%$ & $14.29 \%$ & $15.76 \%$ \\
Total \% & $10.88 \%$ & $2.63 \%$ & $2.25 \%$ & 533 \\
Totals & 457 & 40 & 36 & $100.00 \%$ \\
Total \% & $85.74 \%$ & $7.50 \%$ & $6.75 \%$ & \\
\hline
\end{tabular}

The students who supported CLIL were likely also to prefer English and vice versa. Out of 457 students, who supported CLIL, 399 (88.9\%) preferred English. Accordingly, 87.3\% percent of participants, who preferred English, supported CLIL (see Table 17).

\section{Discussion}

Research findings revealed a significant support for CLIL, and indicated that English is the most preferred foreign language in Azerbaijan.

These findings add further evidence to the existing literature that CLIL is feasible in multilingual settings. An overwhelmingly strong preference for English in Azerbaijan, where $90 \%$ of the population is bilingual in Russian and Azerbaijani, adds new knowledge to the fact that bilingualism is thought to be not only beneficial for helping to acquire a third language (Jarvis, 2015; Merisuo-Storm, 2007), but also positively affects attitudes to learning of a third language in general (Edwards, 1995; Klein, 1995). Moreover, there was a statistically 
significant relationship between L1 and the attitude to language learning. Although both linguistic groups (Azerbaijani-speakers and Russian-speakers), were supportive of CLIL and English, the level of support among Azerbaijani-speakers was higher. These findings are also in line with Laurén (1994) and Lasagabaster (1998) who maintain that sociocultural factors have an important role in learning second or third languages.

This study did not find relationship between gender and attitude towards CLIL and foreign language learning. It is in line with Merisuio-Storm (2007), who did not find any gender differences in the attitude of participants towards language learning in Finnish primary education, but deviate from the findings of Wright (1999), Kobayashi (2002), Cenoz (2001), Lasabagaster \& Sierra (2009) who found significant differences in the attitude towards language learning among female and male learners.

The data collected on social class and income level was limited due to local circumstances as explained above, and findings should be interpreted cautiously. In terms of preference for CLIL, the analysis did not find statistically significant relationship with the variable of ownership form of the educational institutions, which acted as proxy for social class. Students from public and private universities supported CLIL almost on the same level. This finding is in line with Lasabagaster \& Sierra's (2009) study who did not find significant relationship between the attitude to English learning and social class factor. Nevertheless, there was noticeable difference in attitude to English due to the variable of social class. Students enrolled in private universities were more favorable towards English than those enrolled in public universities. It is in line with Clark and Trafford, who found that individuals from lower income classes are less convinced of the value of learning a foreign language (Clark \& Trafford, 1996, p. 49).

The strong relationship between the attitudes to English and CLIL also deserves attention. Supporters of CLIL are more likely (88.9\%) to prefer English than those who did not support CLIL $(75 \%)$. This finding is line with Merisuo-Storm, (2007), Papaja (2012) who found that the participants who favor CLIL will likely also prefer the English language.

The obtained statistical significance sheds some new light on theories of (a) the relationship between the language of education and second/foreign language acquisition, and (b) attitude. The theory drawn forward by Gardner (1985a, 1985b), suggests that attitudes to language acquisition depend on attitudes towards the second/foreign language community, target language and language learning. Findings from this work generate the question whether the first language affects person's willingness to acquire languages, or specifically the Russian as L1 affects the attitude of learners towards English. Moreover, L1 seems to be one of the important elements that shape attitude Laurén (1994) and Lasagabaster (1998).

Future research would be useful to examine the reasons of observed significant relationship between L1 and the attitudes to English and CLIL to find out whether multilingual persons are less willing to learn an additional language than monolinguals do or that receiving education in Russian affects the attitude to English in the Azerbaijani context.

Overall, the findings suggest that multilingual societies such as Azerbaijan generally support language-learning approaches that help preserve and enhance multilingualism. This finding reinforces the concept put forward by Merisuo-Storm, (2007), who found that multilingual people are open to learn additional languages. Such a strong support for CLIL brings new space for maneuvering for decision makers in language policy and planning, for which the question of which language is of paramount importance (Mar-Molinero, 2000). CLIL is an approach that draws on the human ability to learn more than one language and makes the question of 'which single language' redundant. Through CLIL, governments can be ensured with linguistic coherence and unity of the education system. It also guarantees respect for human rights. For such language policies, public support is an important factor and it is evidently present in Azerbaijan as it can be inferred from this study. It makes CLIL, a proven approach for managing multilingualism, an advisable choice for language policy and planning of Azerbaijan, where signs of linguistic fragmentation are present and exacerbated by a "sectoral" language teaching policy (Akhundova, 2007; Chríost, 2004). Trilingual (Azerbaijani-English-Russian) and bilingual (Azerbaijani-English or Azerbaijani-Russian) CLIL models seem to be appropriate for Azerbaijan. The feasibility of Russian is conditioned by the availability of resources, geographical, social, and political factors. The role of English is underpinned by its role as the global lingua-franca, and the strong positive attitude to this language among the population as the findings from this work indicate.

\section{References}

Abdullayeva, S. (2014). Russian schools are popular in Azerbaijan/ Русскиешколыв Азербайджане востребованы. Информационно-Аналитический Портал Медиа Холдинга AЗЕРPOC. Retrieved from http://azerros.ru/sodruzhestvo/19013-russkie-shkoly-v-azerbaydzhane-vostrebovany.html 
Akhundova, E. (2007). Member of Parliament Elmira Akhundova: "I am for limiting Russians sectors because our nation has unfortunately been bifurcated"/ДепутатЭльмира Ахундова: Я выступаюзасокращение русскогосектора в Азербайджане, таккак, к сожалению, нашанацияраздвоилась. Retrieved from http://news.day.az/society/100485.html

Ardeo, J. M. G. (2003). Attitude towards English and ESP acquisition as an L2 or L3 at university. University of the Basque Country. Iberica, 6, 109-133.

Brüning, I., \& Purrmann, M. (2014). CLIL pedagogy in Europe: CLIL teacher education in Germany. In D. D. Martina-Agudo (Ed.), English as a foreign language teacher education: Current perspectives and challenges (pp. 315-339). The Netherlands.

Cenoz, J. (2001). Three languages in contact: Language attitudes in the Basque Country. In D. Lasagabaster \& J. M. Sierra (Eds.), Language Awareness in the Foreign Language Classroom. Zarauz, University of the Basque Country.

Chríost, D. M. G. (2004). Language, Identity and Conflict: A Comparative Study of Language in Ethnic Conflict in Europe and Eurasia. London: Routledge.

Clark, A., \& Trafford, J. (1996). Return to gender: boys' and girls' attitudes and achievements. The Language Learning Journal, 14(1), 40-49. http://dx.doi.org/10.1080/09571739685200371

Coyle, D., Hood, P., \& Marsh, D. (2010). CLIL: Content and language integrated learning. UK: CUP.

Edwards, J. (1995). Multilingualism. London: Penguin Books.

Ellis, R. (1994). The study of second language acquisition. Oxford: Oxford University Press.

Fishman, J. A., \& Garcia, O. (2010). The Handbook of Language and Ethnic Identity. Oxford: Oxford University Press.

Gardner, R. C. (1985a). Social psychology and second language learning: The role of attitudes and motivation. GB: London. Edward Arnold.

Gardner, R. C. (1985b). The attitude/motivation test battery: Technical report. University of Western Ontario. Retrieved from http://publish.uwo.ca/ gardner/docs/AMTBmanual.pdf

Hult, F. M., \& Johnson, D. C. (Eds.). (2015). Research Methods in Language Policy and Planning: A Practical Guide. Malden, MA: Wiley-Blackwell.

Ibarraran, A., Lasagabaster, D., \& Manuel, S. J. (2008). Multilingualism and Language Attitudes: Local Versus Immigrant Students' Perceptions. Language Awareness, 17(4), 326-341. http://dx.doi.org/10.2167/la475.0

Jarvis, S. (2015). Influences of Previously Learned Languages on the Learning and Use of Additional Languages. In M. Juan-Garau \& J. Salazar-Noguera, (Eds.), Content-Based Language Learning in Multilingual Educational Environments, Educational Linguistics (pp. 69-86). New York: Springer International Publishing. http://dx.doi.org/10.1007/978-3-319-11496-5_5

Klein, E. C. (1995). Second versus third language acquisition. Is there a difference? Langange Learning, 45, 419-465. http://dx.doi.org/10.1111/j.1467-1770.1995.tb00448.x

Kobayashi, Y. (2002). The role of gender in foreign language learning attitudes: Japanese female students' attitudes towards learning English. Gender Edu, 14, 181-197. http://dx.doi.org/10.1080/09540250220133021

Lasagabaster, D. (1998). Learning English as an L3. ITL Review of Applied Linguistics, pp. 121-122, 51-84.

Lasagabaster, D., \& Sierra, J. M. (2009). Language Attitudes in CLIL and TraditionalEFL Classes. International CLIL Research Journal, 1(2), 4-17.

Laurén, U. (1994). The written production of bilingual and monolingual students. Performance and creativity. Finland: Vaasa. Universitas Wasaensis.

Marenzi, I., Nejdl, W., Okada, A., Connolly, T., \& Scott, P. (2012). I Search Therefore I Learn-Supporting Active and Collaborative Learning in Language Teaching. Collaborative Learning, 2, 103-125. http://dx.doi.org/10.4018/978-1-4666-0300-4.ch006

Mar-Molinero, C. (2000). The Politics of Language in the Spanish-Speaking World: From Colonization to Globalization. London: Routledge.

Marsh, D., \& Langé, G. (Eds.). (2000). Using Languages to Learn and Learning to Use Languages. Jyväskylá, 
Finland: UniCOM, University of Jyväskylä on behalf of TIE-CLIL.

Merisuo-Storm, T. (2007). Pupils' attitudes towards foreign-language learning and development of literacy skills in bilingual education. Teaching Teacher Edu, 23, 226-235. http://dx.doi.org/10.1016/j.tate.2006.04.024

Papaja, K. L. (2012). The impact of students' attitudes on CLIL. Latin American Journal of Content \& Language Integrated Learning, 5(2), 28-56. http://dx.doi.org/10.5294/lacli1.2012.5.2.10

Pashayeva, G. (2015). Use of foreign language in Azerbaijan/Azərbaycandabeynəlxalqdillərin işlədilməsi. Strateji Tahlil, 1(12), 43-59.

Starkey, H. (2002). Democratic citizenship, languages, diversity and human rights: Guide for the development of Language Education Policies in Europe from Linguistic Diversity to Plurilingual Education. The Open University, Council of Europe. Retrieved from https://www.coe.int/t/dg4/linguistic/Source/StarkeyEN.pdf

Swietochowski, T. (1986). Soviet Azerbaijan today: The problems of group identity. Occasional Paper Vol. 211. Washington, D. C. Kennan Institute for Advanced Russian Studies.

The State Statistical Committee of the Republic of Azerbaijan. (2015). Population by ethnic groups, native language and freely command of languages. Retrieved from http://www.stat.gov.az/source/demoqraphy/indexen.php

Vzglyad. A. Z. (2013). The number of Russian schools in Azerbaijan is made public/Обнародовано количестворусскихшкол в Азербайджане. Retrieved from http://vzglyad.az/haber_-7094-xeber.html

Walden, G. R. (2014). Public Opinion Polls and Survey Research: A Selective Annotated Bibliography of U. S. Guides \& Studies from the 1980s. London: Routledge.

Weber, M. (1978). In G. Roth \& W. Claus (Eds.), Economy and Society: An outline of Interpretive sociology. Berkeley: University of California Press.

Wright, M. (1999). Influences of learner attitudes towards foreign language and culture. Educational Research, 41, 197-208. http://dx.doi.org/10.1080/0013188990410207

\section{Appendix A: Survey Questionnaire Translation of the Survey Questionnaire (Original in Azerbaijani and Russian) \\ Survey questionnaire}

This survey questionnaire is made for the purposes of research by Jamala Mammadova, PhD student at the Free University of Brussels. The aim of the research is to find out the attitude of people to implementation of CLIL (Content and Language Integrated learning) in the education system of Azerbaijan, as well as people attitude towards foreign language preference.

Ethics: Participation in this survey is voluntary. You may refuse to respond this questionnaire without any negative consequences. Your responses will remain anonymous and confidential, and no information that could reveal your identity will be used.

Name (optional)

Surname (optional)

Affiliated education institute

Gender Male $\square \quad$ Female

Age

Which language did/do you receive your secondary school education?

Azerbaijani $\square \quad$ Russian $\square \quad$ English $\square \quad$ Other (please specify)

Research questions

Do you support the implementation of CLIL (Content and language integrated learning) in the education system of Azerbaijan?

YES

Which foreign language do you consider the best foreign language in Azerbaijan?

English $\square$ Russian $\square$ Other (please specify) 


\section{Copyrights}

Copyright for this article is retained by the author(s), with first publication rights granted to the journal.

This is an open-access article distributed under the terms and conditions of the Creative Commons Attribution license (http://creativecommons.org/licenses/by/4.0/). 